\title{
Biological and Analytical Investigations of Alpha-Glucosidase Inhibitory and Anti- Oxidant Activities on Selected Malaysian Medicinal Plants
}

(Penyelidikan Biologi dan Analisis Perencatan Alfa-Glukosidase serta Aktiviti Anti-Oksidan dalam Tumbuhan Ubatubatan Terpilih di Malaysia)

\author{
Nooraqilah Che Rozenan, Nor Hisam Zamakshshari, LeOng KoK HoOng, NaJihah Mohd Hashim, \\ Khadher Ahmad, Munirah Abd RazzaK, Zulkifli Mohd Yusoff, Khalijah Awang, Abd Aziz Ismail \& \\ ROZANA OTHMAN*
}

\begin{abstract}
This study was performed to establish anti-diabetic and anti-oxidant properties, and to carry out phytochemical analysis of selected local plants which are traditionally used as medicinal plants. Local plants involved in this study were Lawsonia inermis, Punica granatum, Dryobalanops aromatica, Ziziphus mauritiana, and Ocimum basilicum. Solvent extraction was performed using maceration method with solvents of increasing polarity. Alpha-glucosidase inhibition assay was performed on all extracts to ascertain their anti-diabetic potentials. The extracts were screened for antioxidant activity using anti-oxidant assays (FRAP, DPPH, TAOC, ABTS, and BCB) and quantitative phytochemical analyses (TPC and TFC). Chemical profiling using LCMS and GCMS was performed on extracts with high biological activities. Methanol extracts of D. aromatica bark and leaves showed the most potent inhibition of alpha-glucosidase with $I C_{50}$ values of $0.63 \pm 0.03 \mu \mathrm{g} / \mathrm{mL}$ and $0.98 \pm 0.02 \mu \mathrm{g} / \mathrm{mL}$, respectively. Both extracts exhibited similar anti-oxidant activity on all five assays and possessed high phenolic contents with values of 266.79 and 261.69 GAE, respectively. The results obtained suggested that amongst the selected plants studied, D. aromatica showed high anti-oxidant activity and anti-diabetic activity (via inhibition of alpha-glucosidase). This is the first report that highlights the anti-diabetic potential of $\mathrm{D}$. aromatica.
\end{abstract}

Keywords: Alpha-glucosidase; anti-diabetic; anti-oxidant; Dryobalanops aromatica; medicinal plants

ABSTRAK

Kajian ini dijalankan bagi mengenal pasti ciri-ciri anti-diabetik dan anti-oksidan, serta analisis fitokimia terhadap tumbuhan tempatan terpilih yang digunakan secara tradisi sebagai tumbuhan ubatan. Tumbuhan tempatan yang terlibat dalam kajian ini adalah Lawsonia inermis, Punica granatum, Dryobalanops aromatica, Ziziphus mauritiana dan Ocimum basilicum. Pengekstrakan pelarut telah dijalankan melalui kaedah maserasi menggunakan pelarut-pelarut dengan peningkatan kepolaran. Asai perencatan alfa-glukosidase telah dijalankan ke atas semua ekstrak bagi mengenal pasti keupayaan anti-diabetik. Kesemua ekstrak juga telah disaring untuk aktiviti anti-oksidan menggunakan asaiasai anti-oksidan (FRAP, DPPH, TAOC, ABTS dan BCB) dan analisis fitokimia kuantitatif (TPC dan TFC). Pemprofilan kimia telah dijalankan ke atas ekstrak dan fraksi yang mempunyai aktiviti biologi yang tinggi dengan menggunakan LCMS dan GCMS. Ekstrak metanol bagi kulit dan daun D. aromatica menunjukkan perencatan alfa-glukosidase yang paling tinggi dengan nilai $I C_{50}$ masing-masing adalah $0.63 \pm 0.03 \mu \mathrm{g} / \mathrm{mL}$ dan $0.98 \pm 0.02 \mu \mathrm{g} / \mathrm{mL}$. Kedua-dua ekstrak menunjukkan aktiviti anti-oksidan yang tinggi ke atas kelima-lima ujian anti-oksidan, serta mempunyai kandungan fenol yang tinggi dengan nilai masing-masing 266.79 dan 261.69 GAE. Hasil uji kaji yang diperoleh menunjukkan bahawa D. aromatica mempunyai aktiviti anti-oksidan dan aktiviti anti-diabetik yang tinggi (melalui perencatan alfaglukosidase). Laporan ini adalah yang pertama kalinya merekodkan keupayaan anti-diabetik bagi D. aromatica.

Kata kunci: Alfa-glukosidase; anti-diabetik; anti-oksidan; Dryobalanops aromatica; tumbuhan ubatan 


\section{INTRODUCTION}

The American Diabetes Association (ADA) classifies diabetes mellitus as a complex metabolic disease (ADA 2006). It is a chronic endocrine disorder that disturbs the metabolism process of proteins, carbohydrates, fat, water, and electrolytes (Nair et al. 2013). It is characterized by glucose intolerance and hyperglycemia which occur because of insulin deficiency, defect in the insulin's action or a combination of both (Deutschländer et al. 2009). There are different types of diabetes mellitus where type 1 and 2 are the most common. Less than $10 \%$ of all diabetic cases are due to the autoimmune destruction of beta cells resulting in type 1 diabetes, whereas about $90 \%$ are affected by type 2 diabetes due to the impaired effectiveness of insulin secretion and/or action (Szkudelski \& Szkudelska 2011). Type 2 diabetes mellitus is a progressive and complex disorder which in the long term is difficult to manage effectively and considered to be a non-curable but controllable disease (Kim et al. 2009).

Studies showed that absorption inhibitors play a role in preventing diabetes mellitus in high risk populations (Cheng \& Josse 2004). Hence, a method to treat diabetes is to decrease postprandial hyperglycemia by inhibiting the carbohydrate hydrolysing enzymes such as alpha-amylase and alpha-glucosidase. These enzymes play a crucial role in the digestion of carbohydrates (Nair et al. 2013). Alpha-amylase is an important enzyme that is present in the pancreatic juice and saliva. It breaks down long carbohydrate chains such as large insoluble starch molecules into molecules that can be absorbed (Kazeem et al. 2013). Alpha-glucosidase on the other hand is a glycosylphosphatidyl-anchored enzyme in the mucosal brush border of the small intestine that catalyses the final step in carbohydrate digestion by hydrolysing the carbohydrate on the 1,4-alpha linkages, releasing alpha-D-glucose (Sivasothy et al. 2016). Blocking the process of carbohydrate breakdown, thereby diminishing the postprandial blood glucose excursion, can be achieved by inhibiting the alpha-amylase and alpha-glucosidase enzymes (Kwon et al. 2007). New inhibitors of alphaamylase and alpha-glucosidase enzymes have been shown as potential leads in developing new drugs for the treatment of diabetes (Nair et al. 2013).

At present, anti-diabetic drugs such as acarbose, which is a commercial inhibitor, is used as a treatment for diabetes patients to control postprandial hyperglycemia (Tabussum et al. 2013). Even though current drugs are able to reduce hyperglycemia in diabetic patients, prolonged usage is associated with side effects such as liver toxicity, abdominal distention, flatulence, meteorism, and increased occurrence of diarrhoea (Hollander 1992; Sivasothy et al. 2016). Therefore, compounds from natural resources as new inhibitors with potentially less side effects may offer better treatment outcomes (Rege \& Chowdhary 2014). Inhibitors from plants had been reported to display high inhibition against alpha-glucosidase activity and low inhibition against alpha-amylase activity, which is preferable because excessive inhibition of the pancreatic alpha-amylase will result in increased bacterial fermentation of undigested carbohydrates in the colon, leading to an increased incidence of diarrhoea (Kim et al. 2009). It was noted by the World Health Organization (WHO) that traditional plant remedies for diabetes may offer better treatment options because of their effectiveness, fewer side effects and, are preferable for oral therapy (Shokeen et al. 2008).

Malaysia is known for its abundant tropical biodiversity rich with many medicinal plants that were inspired from different practices, religions, and traditional beliefs. In this study, among the locally grown plants chosen to be tested for anti-diabetic and antioxidant activities were Lawsonia inermis (henna), Punica granatum (pomegranate), Dryobalanops aromatica (Borneo camphor tree), Ziziphus mauritiana (jujube) and Ocimum basilicum (basil). These plants were also mentioned in Al-Quran and Hadith, hence, are used amongst muslim communities. Additionally, the plants were also chosen because of their wide use in Malaysia not only as food but also used as traditional medicines to treat different ailments (Ahmad et al. 2015; Ganesh \& Amit 2013; Le et al. 2016; Salleh et al. 2019; Syamsudin \& Winarno 2008; Zhang et al. 2010).

Dryobalanops aromatica belongs to the family Depterocarpaceae and is grown in Malaysia. This plant has been a source of camphor (obtained from the bark) as early as in the ninth century. D. aromatica is more commonly known as camphor tree, Borneo camphor, Malay camphor or Sumatran camphor. Locally it is called 'pokok kapur barus' (Ashton 1983; Donkin 1999). The branches and leaves of this plant are employed orally for gum swelling, cholera, and breast pain (Ali 2014). It has been reported that this plant contains terpenoids such as D-borneol, terpinen-4-ol, alpha-terpineol, alphapinene, and caryophyllene, which is known for its antimicrobial, cytotoxic, and anti-inflammatory activities (Le et al. 2016). 
Punica granatum, from the family Punicaceae, is commonly known as pomegranate and locally called 'delima' (Radhika et al. 2011). The ash of the young leaves of pomegranate is used traditionally by mixing with water and consumed to treat gastrointestinal ailments. The juice and/or peel has been used to treat vaginal white discharges, leucorrhea, treating intestinal worms and for slimming purposes (Ong \& Norzalina 1999; Ong et al. 2011). P. granatum had been reported to exhibit anti-proliferative, anti-bacterial and antidiarrheal activities (Radhika et al. 2011; Zhang et al. 2010). It contains anthocyanins, phenolics, polyphenols, tannins, flavonoids, proanthocyanidin, ellagitannins, and minerals such as nitrogen, calcium, magnesium, sodium, phosphorus and potassium (Heftmann et al. 1966; Moneam et al. 1988; Poyrazoğlu et al. 2002; Viuda-Martos et al. 2010).

Lawsonia inermis, commonly known as henna and locally called inai, belongs to the family Lythraceae. Henna has been used traditionally in Malaysia as colouring and used traditionally for ringworm, dandruff, inflammatory conditions, calculus affliction, jaundice, stomach disorder, sore throat, skin diseases, diabetes, and rheumatism (Alia et al. 1995; Badoni Semwal et al. 2014; Othman et al. 2020; Sultana et al. 2009). L. inermis has various biological activities such as anti-inflammation, hypoglycemic, analgesic, immunostimulant, anti-microbial and antiviral (Agarwal et al. 2014; Muhammad \& Muhammad 2005). Phytochemical studies of $L$. inermis reported the presence of lawsone, gallic acid, tannic acid, alphaD-glucose, esculetin, fraxetin, isoplumbagin, scopoletin, betulin, betulinic acid, hennadiol, lupeol, lacoumarin, and laxanthone (Nik et al. 2012; Sultana et al. 2009).

Ziziphus mauritiana, locally known as 'pokok bidara' and commonly known by many names such as jujube, Indian jujube, and chinese apple, is a tropical fruit tree from the Rhamnacease family (Ganesh \& Amit 2013). The fruit is well known as it is used to treat ailments such as cuts and ulcers as well as for fevers and pulmonary ailments. Traditionally, the plant part is used as a tonic, anti-cancer, sedative, and for treating fever (Ganesh \& Amit 2013). Furthermore, it has been used in treating insomnia, hemorrhage, diarrhea, and anxiety problems (Salleh et al. 2019; Sun et al. 2011). Studies on Z. mauritiana had shown biological activities such as antimicrobial, anti-cancer, anthelmintic, hepatoprotective, anti-obesity, and wound healing (Ganesh \& Amit 2013). The plant is reported to contain flavonoids, alkaloids, saponins, resins, polyphenols, mucilage and vitamins (Jain et al. 2012; Jarald et al. 2009; Rahman 2012).

Ocimum basilicum, commonly called basil, common basil or sweet basil, and locally known as 'selasih', is part of the Lamiaceae family, and is widely cultivated for its medicinal and religious purposes (Ahmad et al. 2015). The plant is used as a tonic, and the infusion made from the leaves is used in treating nausea, flatulence, and dysentery. It is also used in alleviation of spasm, rhinitis, mental fatigue, cold, and for wasp stings and snake bites (Ahmad et al. 2015). O. basilicum extract showed potential biological activities such as analgesic, anti-inflammation, hypoglycemic and hepatoprotective, anti-microbial, anti-cancer, and anti-ulcer (Ahmad et al. 2015). The plant is reported to contain chemical constituents such as monoterpene hydrocarbons, sesquiterpene hydrocarbons, oxygenated sesquiterpenes, flavonoids, oxygenated monoterpenes, triterpenes, and aromatic compounds (Marwat et al. 2011).

One of the major hypotheses proposed that the imbalance between the reactive oxygen species capacity and the anti-oxidant defense capacity results in the onset of diabetes (Dehghan et al. 2016). It has been reported that oxidative stress could have a role in the pathogenesis of secondary diabetic complications (Ceriello 2000), and anti-oxidants have been considered as treatments (Cunningham 1998). Plants are known to contain a substantial amount of anti-oxidants such as flavonoids (Larson 1988). Hence, it can be postulated that using anti-oxidants can be useful in scavenging various reactive oxygen species and the prevention of diabetes mellitus.

Phenolic compounds are known to have anti-oxidant properties. These compounds usually exhibit oxidative activities via several mechanisms of action which include singlet oxygen quencher, hydrogen donating anti-oxidant, free radical scavenger, and metal ions chelator (Ruhomally et al. 2015). The biological activities of extracts might be due to the phenolic compounds contained in the extracts (Saeed et al. 2012). Consequently, this study will also explore the anti-oxidant activity of all the plant extracts as well as quantitative phytochemical analysis on each crude extract. Chemical profiling on LCMS and GCMS was done for extracts that exhibited high biological activities. 


\section{Materials AND Methods}

\section{PLANT MATERIALS}

All plant materials were collected locally in Malaysia, identified and confirmed by a botanist from the Faculty of Science, Universiti Malaya, Malaysia. The herbarium specimens of $L$. inermis (voucher no: KL5824), $P$. granatum (KL5826), D. aromatica (KL5829), Z. mauritiana (KL5828), and O. basilicum (KL5825) were prepared and stored in the herbarium of the Department of Chemistry, Faculty of Science, Universiti Malaya, Malaysia.

\section{PREPARATION OF PLANT EXTRACTS}

Parts of the plant, barks, leaves and seeds were rinsed with water, sliced and air dried at room temperature. The dried plant materials were put through the extraction process by maceration method. The dried plant samples were soaked in hexane with periodical stirring for a period of three days. On the third day, the hexane extracts were filtered and concentrated using the rotary evaporator (BUCHI R-114). This process of extraction was repeated two more times. Following this, the maceration extraction process was repeated using solvents with increasing polarities, which were ethyl acetate, followed by methanol (Handa et al. 2008). The plant materials were then soaked in distilled water and boiled three times up to $30 \mathrm{~min}$ each time to yield the water extracts. Once the solutions had cooled down, the extracts were filtered and freeze dried to obtain the dried water extract (Chen et al. 2009).

\section{BIOLOGICAL EVALUATIONS OF PLANT EXTRACTS AND QUANTITATIVE PHYTOCHEMICAL ANALYSIS}

\section{ALPHA-GLUCOSIDASE INHIBITORY ACTIVITY}

Two-fold serial dilution was carried out from a stock solution of $100 \mu \mathrm{g} / \mathrm{mL}$ of the extracts, and $40 \mu \mathrm{L}$ of various concentrations of the extracts were pre-incubated with 80 $\mu \mathrm{L}$ of 2 unit/mL alpha-glucosidase enzyme (dissolved in $67 \mathrm{mM}$ potassium phosphate buffer, $\mathrm{pH}$ 6.8) for 10 min. A total of $40 \mu \mathrm{L}$ of $5 \mathrm{mM}$ p-nitrophenyl-alphaD-glucopyranoside solution ( $\mathrm{p}-\mathrm{NPG}$ ) was added and incubated for $10 \mathrm{~min}$. To stop the reaction, $60 \mu \mathrm{L}$ of 100 $\mathrm{mM}$ of sodium carbonate was added and the absorbance taken at a wavelength of $415 \mathrm{~nm}$ (Infinite M200PRO). The standard inhibitor used in the experiment was acarbose, and the determination of the half maximal inhibitory concentration $\left(\mathrm{IC}_{50}\right)$ was carried out using GraphPad Prism 6 statistical package (GraphPad Software, USA). The data was expressed as mean \pm standard deviation of triplicate determinations (Sivasothy et al. 2016).

\section{ANTI-OXIDANT ASSAY}

All extracts were screened for their anti-oxidant activities using five assays, namely DPPH (2, 2-diphenyl1-picrylhydrazyl), Beta-Carotene Bleaching (BCB), Ferric Reducing Power (FRAP), Total Anti-oxidant Capacity (TAOC), and ABTS 2,2'-azino-bis (3-ethylbenzothiazoline6-sulphonic acid). DPPH radical-scavenging activities of all extracts were determined using the method described by Nordin et al. (2014). Gallic acid was used as a standard in this experiment and absorbance read at $517 \mathrm{~nm}$ using microplate absorbance reader (Infinite M200PRO) after $30 \mathrm{~min}$ incubation at room temperature.

The BCB assay was conducted according to the protocol by Zamakshshari et al. (2019). Gallic acid was used as a positive control. The absorbance was measured at $470 \mathrm{~nm}$ at 0 and $2 \mathrm{~h}$. The percentage of BCB between all extracts $(1 \mathrm{mg} / \mathrm{mL})$ and positive control $(100 \mu \mathrm{g} / \mathrm{mL})$ were compared. The reducing power of the extracts and gallic acid were determined according to Nordin et al. (2014). A standard curve of gallic acid was constructed and a standard equation was determined. This equation would result in finding the reducing power (FRAP) for these extracts. The reducing power results were expressed relative to gallic acid equivalent (GAE, $\mu \mathrm{g}$ of gallic acid/ $\mathrm{mg}$ of extract). Each extract was screened at $1 \mathrm{mg} / \mathrm{mL}$.

TAOC assay is a non-enzymatic assay that is capable to measure the anti-oxidant capacity. This assay was performed following the protocol reported by Sun et al. (2011). All extracts were screened at a concentration of $1 \mathrm{mg} / \mathrm{mL}$ and analysed at $695 \mathrm{~nm}$. The total anti-oxidant activity was expressed as equivalent to ascorbic acid.

Free radical scavenging assay was performed by using the ABTS method as described by Dudonne et al. (2009), with slight modification. The method involved $10 \mu \mathrm{L}$ of $1 \mathrm{mg} / \mathrm{mL}$ sample (diluted in DMSO) pipetted into a $96-w e l l$ microplate, followed by $300 \mu \mathrm{L}$ of ABTS $+\bullet$ solution. DMSO was used as a blank. The plate was kept for $10 \mathrm{~min}$ at $30{ }^{\circ} \mathrm{C}$. The absorbance was then recorded at $743 \mathrm{~nm}$. The ABTS was decolorized as a result of the scavenging activity of the anti-oxidant. 
TOTAL PHENOLIC CONTENT (TPC) AND TOTAL FLAVONOID CONTENT (TFC)

The total phenolic content (TPC) of each extract was determined using the Folin-Ciocalteu assay, a method by Kahkonen et al. (1999). The TPC assay was carried out in a 96-well flat bottom plate. Gallic acid was used as a standard. The TPC of each crude extract was expressed as gallic acid equivalent, GAE ( $\mu$ g of gallic acid/mg extract). Meanwhile, the total flavonoid contents (TFC) of the extracts were determined according to the method by Ceriello (2000). Quercetin was used as a standard in this experiment. The TFC was expressed as quercetin equivalent, $\mathrm{QE}$ ( $\mu \mathrm{g}$ of $\mathrm{QU} / \mathrm{mg}$ of crude extract).

\section{CHEMICAL PROFILING USING LCMS}

A solvent system in LCMS consisting of $0.1 \%$ formic acid in water (solvent A) and acetonitrile (solvent B) was used with the following gradient: starting with $100 \% \mathrm{~B}$ and installing a gradient to obtain $50 \% \mathrm{~B}$ at 18 $\mathrm{min}$, and finally to $5 \% \mathrm{~B}$ from 18 at $20 \mathrm{~min}$. The system controller was stopped at the end of $20 \mathrm{~min}$. The solvent flow rate was $0.8 \mathrm{~mL} / \mathrm{min}$. Samples $(10 \mu \mathrm{L})$ were injected onto a C18 reversed-phase column $(150 \mathrm{~mm} \times 4.6 \mathrm{~mm}$ i.d, $3.0 \mu \mathrm{m}$ particle size). Mass spectrometric detection was performed with a QTOF-MS operated in the positive mode. Information dependent acquisition was done using a QTOF-MS survey scan 100 - $1100 \mathrm{Da}(100 \mathrm{~ms})$ and up to 10 dependent QTOF-MS scans 100 - $1100 \mathrm{Da}$ (100 $\mathrm{ms}$ ) using Collision Energy (CE) of $45 \mathrm{~V}$ with Collision Energy Spread (CES) of $\pm 30 \mathrm{~V}$. The identification of the peaks was conducted against the Metlin and Chemspider databases.

\section{CHEMICAL PROFILING USING GCMS}

The GCMS column used was RTX-5MS fused-silica capillary column $(30 \mathrm{~m} \times 0.25 \mathrm{~mm}$ i.d.; $0.25 \mu \mathrm{m}$ film thickness) with helium as the carrier gas and was run at a constant pressure of $100.0 \mathrm{kPa}$. Injection was conducted using the splitless mode at an injector temperature of 300 ${ }^{\circ} \mathrm{C}$. The oven temperature was ramped from 40 to $160{ }^{\circ} \mathrm{C}$ ( 5 min hold) at a rate of $4{ }^{\circ} \mathrm{C} / \mathrm{min}$, and $160-280{ }^{\circ} \mathrm{C}(15$ min hold) at $5{ }^{\circ} \mathrm{C} / \mathrm{min}$ (rate). The total run time for each sample was approximately $74 \mathrm{~min}$. The GCMS interface temperature was set to $280^{\circ} \mathrm{C}$. MS mode was used during analytical scanning from 45-500 atomic mass units (amu). The ion source temperature was set to $280{ }^{\circ} \mathrm{C}$.
The identification of the peaks was conducted against the National Institute of Standard and Technology Mass Spectral Library (NIST08 and 08s).

\section{STATISTICAL ANALYSIS}

The alpha-glucosidase inhibitory activity, anti-oxidant test, and phytochemical analysis data were represented as mean \pm standard deviation, and were carried out in triplicate independent analyses. The graphs were generated using Microsoft Excel Software (Version 2010). Data were analyzed using one-way ANOVA via Tukey's post hoc test (SPSS 14.0) to determine the significant differences between sample activities. Meanwhile, the independent sample t-test (SPSS 14.0) was used to determine any significant difference in activity between samples and standard drugs. Pearson correlation (SPSS 14.0) was used to determine the correlation of alphaglucosidse activity with TPC and TFC. The significance level was set at $\mathrm{p}<0.05$.

\section{RESULTS AND DISCUSSION}

The inhibitory activities of forty-four plant extracts of Dryobalanops aromatica, Ziziphus mauritiana, Lawsonia inermis, Ocimum basilicum, and Punica granatum against alpha-glucosidase were screened and the results obtained are shown in Figure 1. Furthermore, alpha-glucosidase assay was conducted as plants were noted to have higher inhibition against alphaglucosidase and lower inhibition against alpha-amylase leading to reduced side effects. Further investigation of the antidiabetic activity of potential extracts will be conducted after preliminary screening (Kim et al. 2009).

The enzyme used to investigate the alphaglucosidase inhibitory activity was obtained from yeast (Saccharomyces cerevisiae). This assay was evaluated based on the development of yellow colour of p-nitrophenol by employing p-NPG as the substrate (Rege \& Chowdhary 2014). Out of the forty-four plant extracts, thirty-four of them displayed inhibitory activity against alpha-glucosidase enzyme with $\mathrm{IC}_{50}$ ranging from 0.63 to $94.71 \mu \mathrm{g} / \mathrm{mL}$, which were better inhibition compared to the standard acarbose $\left(\mathrm{IC}_{50}=1067.67 \mu \mathrm{g} / \mathrm{mL}\right)$. Twenty-eight of the plant extracts showed $\mathrm{IC}_{50}$ less than $50.00 \mu \mathrm{g} / \mathrm{mL}$, while only six of the plant extracts showed $\mathrm{IC}_{50}$ in the range of $50.00-100.00 \mu \mathrm{g} / \mathrm{mL}$. From the twenty-eight extracts with $\mathrm{IC}_{50}$ below $50.00 \mu \mathrm{g} / \mathrm{mL}$, fourteen of them showed high 


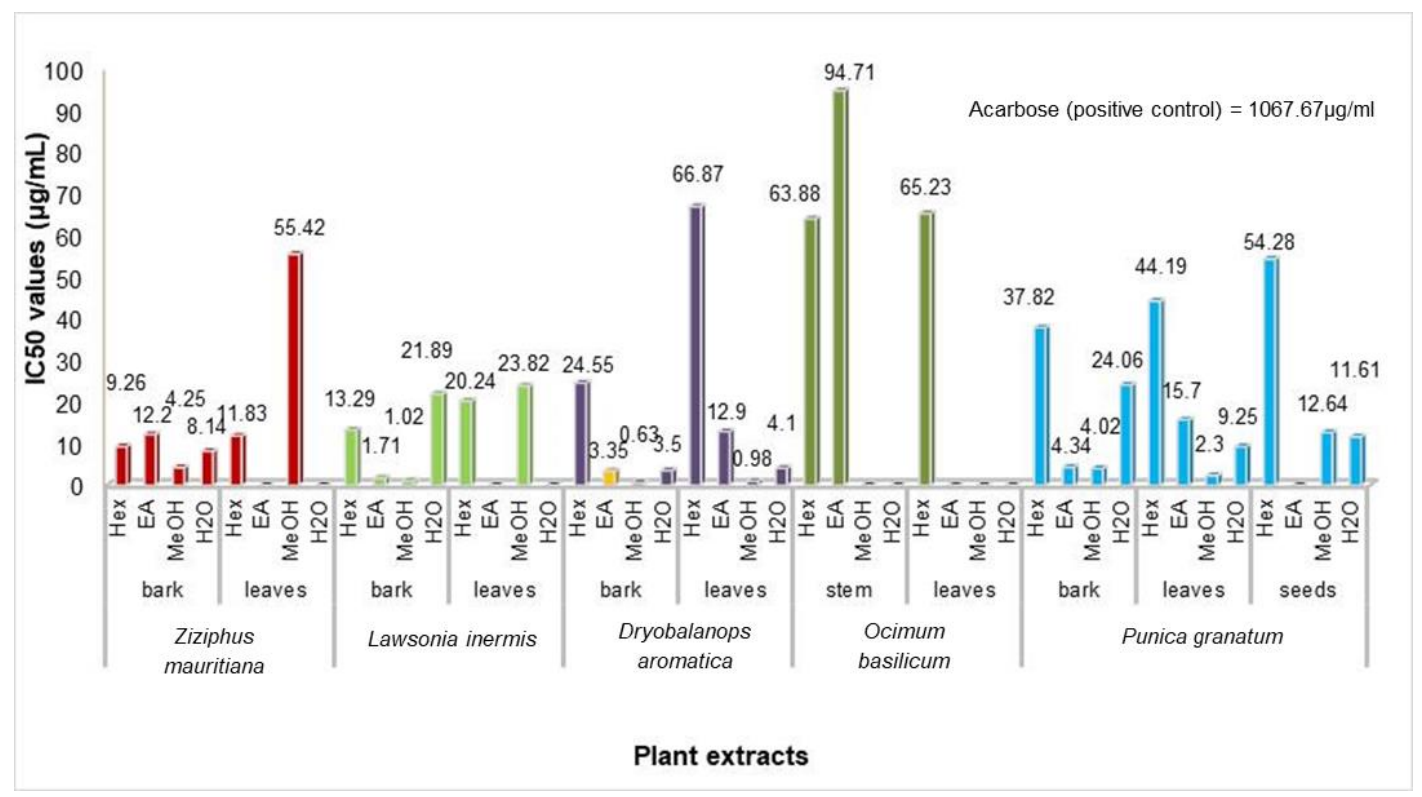

FIGURE 1. The $\mathrm{IC}_{50}$ values of different plants extracts against alpha-glucosidase

$\left({ }^{*} \mathrm{Hex}=\right.$ Hexane, $\mathrm{EA}=$ Ethyl acetate, $\mathrm{MeOH}=$ Methanol, $\mathrm{H} 2 \mathrm{O}=$ Water $)$

inhibitory activity with $\mathrm{IC}_{50}$ less than $10.00 \mu \mathrm{g} / \mathrm{mL}$. The methanol extract of $D$. aromatica bark showed the highest inhibitory activity at $\mathrm{IC}_{50}$ of $0.63 \mu \mathrm{g} / \mathrm{mL}$, followed by the methanol extract of $D$. aromatica leaves with $\mathrm{IC}_{50}$ of 0.98 $\mu \mathrm{g} / \mathrm{mL}$. Except for hexane extract, all the extracts of $D$. aromatica showed the highest potential for anti-diabetic activity with $\mathrm{IC}_{50}$ of less than $13.00 \mu \mathrm{g} / \mathrm{mL}$. Conversely, $O$. basilicum plant extracts exhibited the least inhibitory activities with only three of the extracts showed activities with $\mathrm{IC}_{50}$ of more than $60.00 \mu \mathrm{g} / \mathrm{mL}$. The methanol extracts of the barks of $D$. aromatica, $Z$. mauritiana, and $L$. inermis, and of the seeds of $P$. granatum showed the highest inhibitory activities amongst all of the various extracts within each respective plant. It could be deduced that there was a general trend of increasing inhibition activity with increasing polarity of the extraction solvent. However, while the water is a more polar solvent than methanol, the methanol extracts of the mentioned plants exhibited more potent inhibitory activities compared to their respective water extracts. This could be attributed to the different chemical properties of the phytochemical constituents of the respective extracts.

Except for $O$. basilicum which has stem instead of bark extracts, in general, it could be observed that the inhibitory activities of the bark extracts were stronger than the leaves extract for each solvent type. This suggested that the bark extracts have higher potential for antidiabetic applications compared to the leaves extracts. From this study, it can be inferred that $D$. aromatica, $P$. granatum, $Z$. mauritiana, and L. inermis are promising plant candidates for further investigations to be developed into anti-diabetic agents. Contrary to the results obtained for the alpha-glucosidase inhibitory activity, inhibition assay against alpha-amylase showed only the methanol extract of $D$. aromatica bark was active with an $\mathrm{IC}_{50}$ value of $95.51 \mu \mathrm{g} / \mathrm{mL}$, which was less active than acarbose $\left(\mathrm{IC}_{50}=70.31 \mu \mathrm{g} / \mathrm{mL}\right)(\mathrm{SD} 1)$. This observation corroborated with the report by Kim et al. (2009) stating that, generally, natural inhibitors from plant extracts have displayed higher inhibition against alpha-glucosidase enzyme and lower inhibition against alpha-amylase enzyme with minimal side effects.

Phytochemical analysis was carried out on the extracts which included the phenolic content assay and total flavonoid assay. These two assays will quantitively determine the amount of phenolic and flavonoid compounds, respectively, in each extract. The principle of the total phenolic content assay is based on the redox 
reaction properties of anti-oxidant compounds that react with Folin-Ciocalteu reagent to enhance the measurement of the phenolic concentrations (Norshazila et al. 2010). The most polar extract showed high phenolic content compared to the semi-polar and less polar extracts, as shown in Figure 2. However, the total flavonoid content was seen highest in semi-polar extracts (Figure $3)$. Furthermore, correlation studies were conducted on TPC and TFC values of the extracts to determine whether they played a role in inhibiting alpha-glucosidase. The correlation coefficient of TPC with alpha-glucosidase assay is $\mathrm{r}=-0.441, \mathrm{p}=0.004$, and TFC with alphaglucosidase assay is $\mathrm{r}=0.183, \mathrm{p}=0.259$. According to Zamakshshari et al. (2019), correlation coefficients that range from 0.1 to 0.4 indicate a weak correlation, followed by 0.5 to 0.7 correlation coefficients showing moderate correlation and 0.8 to 0.9 correlation coefficients indicate strong correlations. Therefore, coefficient correlations for both TPC and TFC indicate that the alpha-glucosidase inhibitory activities of the extracts are not directly related to the phenolic and flavonoid compounds.

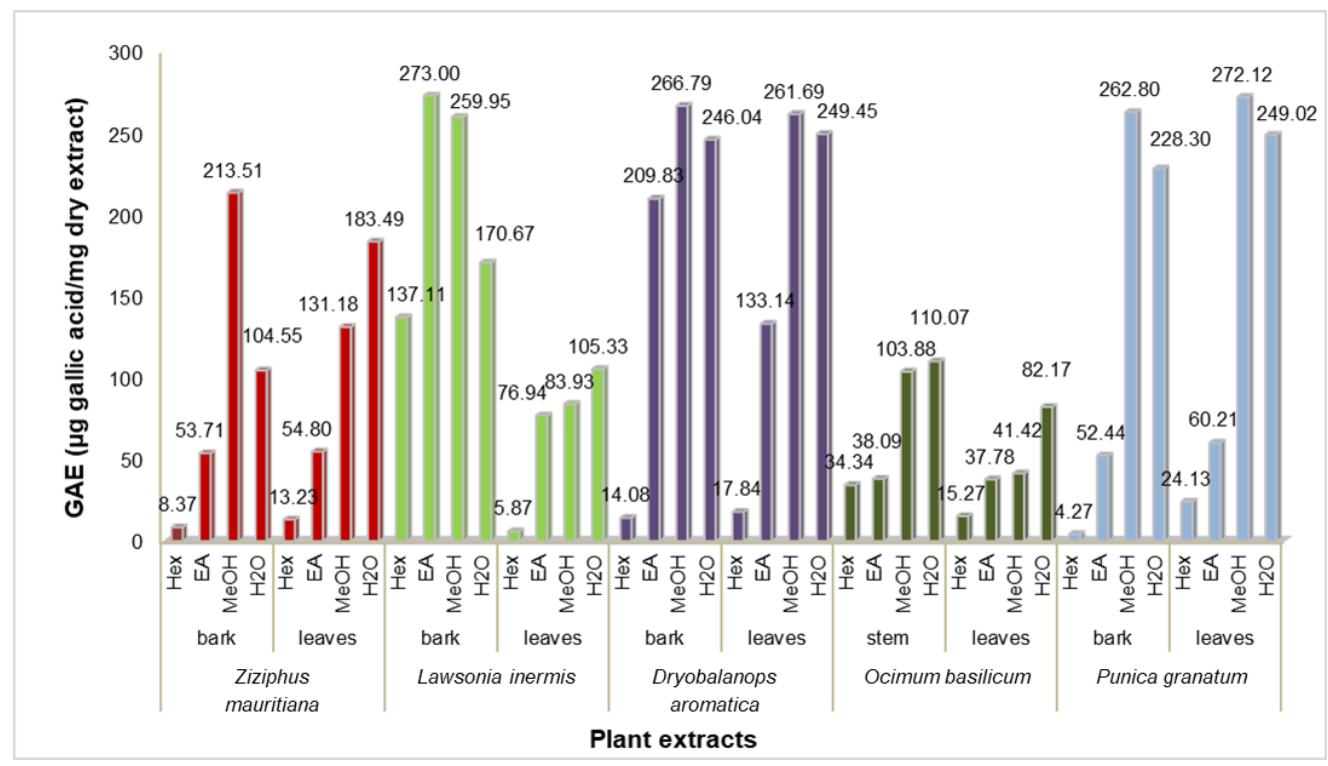

FIGURE 2. Total phenolic content of different plant extracts in GAE

$\left({ }^{*} \mathrm{Hex}=\right.$ Hexane, $\mathrm{EA}=$ Ethyl acetate, $\mathrm{MeOH}=$ Methanol, $\mathrm{H}_{2} \mathrm{O}=$ Water $)$

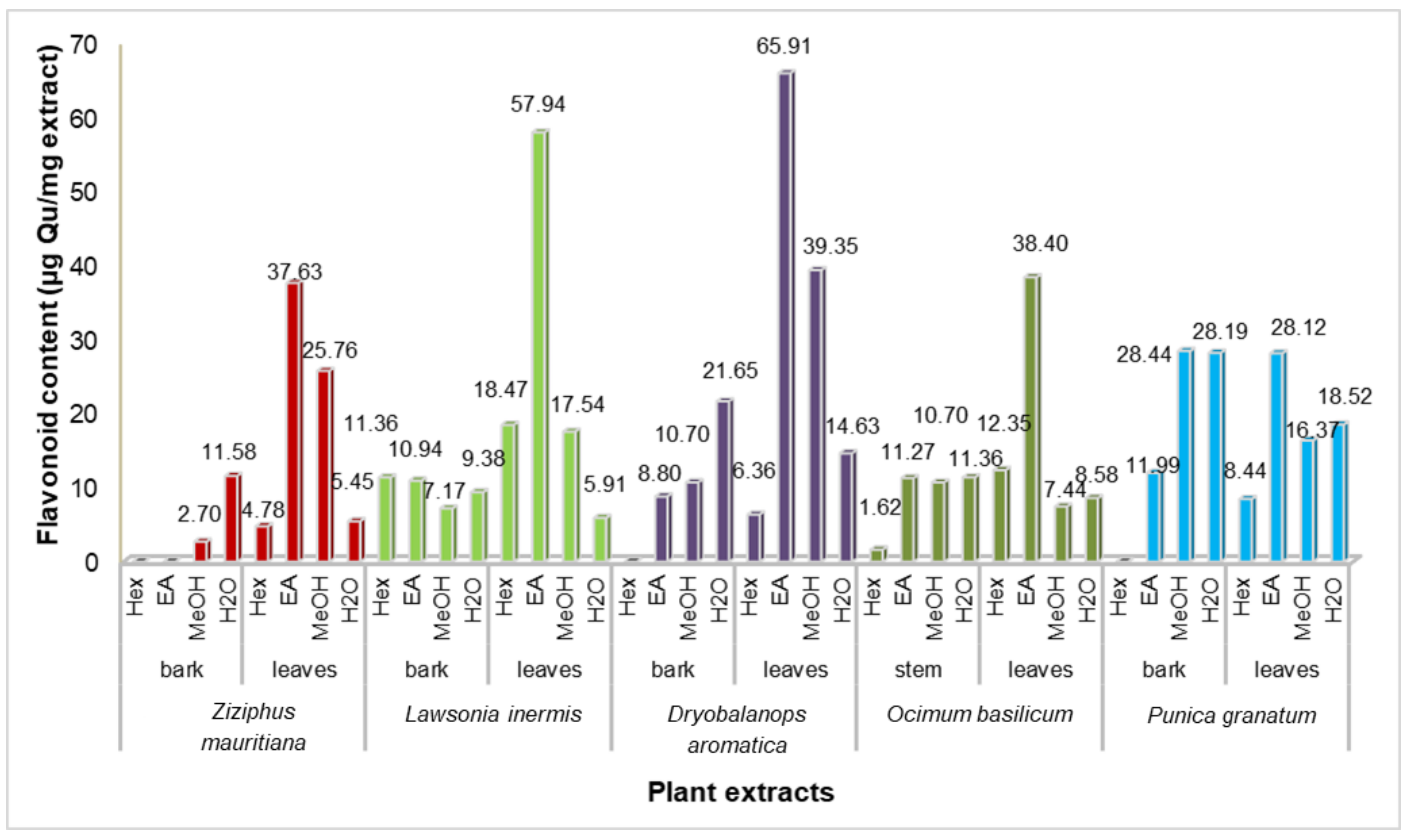

FIGURE 3. Total flavonoid content of different plants extracts

$\left(* \mathrm{Hex}=\right.$ Hexane, $\mathrm{EA}=$ Ethyl acetate, $\mathrm{MeOH}=$ Methanol, $\mathrm{H}_{2} \mathrm{O}=$ Water $)$ 
Five anti-oxidant tests were performed and out of 40 plant extracts, the methanol extract from leaves and bark of $D$. aromatica showed the highest anti-oxidant activity in several anti-oxidant assays compared to others. Table 1 shows methanol leaves extract of $D$. aromatica having the highest ability in reducing $\mathrm{Fe}^{3+}$ to $\mathrm{Fe}^{2+}$ at 1084.13 \pm 20.03 GAE followed by methanol bark extract of $D$. aromatica with $972.71 \mathrm{GAE}$.

TABLE 1. Anti-oxidant activity of the crude extracts of the Malaysian ethnomedicinal plants used in this study

\begin{tabular}{|c|c|c|c|c|c|c|c|}
\hline & & & FRAP & DPPH & TAOC & ABTS & $\mathrm{BCB}$ \\
\hline Plants & Extract & $\begin{array}{c}\text { Plant } \\
\text { part }\end{array}$ & $\begin{array}{c}\text { GAE } \\
\text { ( } \mu \text { g gallic acid/ } \\
\text { mg dry extract) }\end{array}$ & $\begin{array}{c}\mathrm{EC}_{50} \\
(\mu \mathrm{g} / \mathrm{mL} \text { extract })\end{array}$ & $\begin{array}{c}\text { AAE } \\
\text { ( } \mu \mathrm{g} \text { Ascorbic Acid/ } \\
\text { mg of dry extract) }\end{array}$ & $\begin{array}{c}\% \text { of } \\
\text { scavenging } \\
\text { of extract at } 1 \\
\mathrm{mg} / \mathrm{mL}\end{array}$ & $\begin{array}{c}\% \text { of } \\
\beta \text {-carotene } \\
\text { bleaching of } 1 \\
\text { mg extract }\end{array}$ \\
\hline \multirow{8}{*}{$\begin{array}{c}\text { Dryobalanops } \\
\text { aromatica }\end{array}$} & Hex & Bark & NA & $>$ & $48.74 \pm 8.90^{\mathrm{a}, \mathrm{b}, \mathrm{c}}$ & $2.62 \pm 0.46^{*}$ & $62.27 \pm 1.14^{*}$ \\
\hline & Hex & Leaf & NA & $>$ & $48.62 \pm 0.77^{\mathrm{a}, \mathrm{b}, \mathrm{c}}$ & $7.70 \pm 1.02$ & $34.35 \pm 2.63^{*}$ \\
\hline & EA & Bark & $609.97 \pm 8.97^{\mathrm{j}}$ & $56.65 \pm 0.53^{*}$ & $132.43 \pm 0.50^{\mathrm{k}, 1}$ & $92.27 \pm 0.40 *$ & $88.18 \pm 1.48$ \\
\hline & EA & Leaf & $306.31 \pm 28.86^{\mathrm{f}, \mathrm{g}}$ & $112.12 \pm 2.05^{*}$ & $116.46 \pm 21.62^{e, f, g, h, i, j}$ & $77.53 \pm 3.62$ & $86.84 \pm 6.80$ \\
\hline & $\mathrm{MeoH}$ & Bark & $972.71 \pm 46.99^{\mathrm{m}}$ & $24.86 \pm 0.76^{*}$ & $225.22 \pm 10.81^{\circ}$ & $93.77 \pm 0.48$ & $91.26 \pm 1.13$ \\
\hline & $\mathrm{MeoH}$ & Leaf & $1084.13 \pm 20.03^{n}$ & $19.32 \pm 1.24 *$ & $203.05 \pm 16.74^{\mathrm{n}, \mathrm{o}}$ & $93.86 \pm 0.49$ & $91.40 \pm 1.68$ \\
\hline & $\mathrm{H}_{2} \mathrm{O}$ & Bark & $714.93 \pm 32.79^{\mathrm{k}}$ & $45.74 \pm 0.58^{*}$ & $142.11 \pm 7.26^{\mathrm{j}, \mathrm{k}, \mathrm{l}}$ & $93.20 \pm 0.55^{*}$ & $86.44 \pm 1.35$ \\
\hline & $\mathrm{H}_{2} \mathrm{O}$ & Leaf & $807.69 \pm 39.72^{1}$ & $39.73 \pm 0.59 *$ & $119.66 \pm 15.47^{\mathrm{h}, \mathrm{i}, \mathrm{j}}$ & $93.17 \pm 0.54$ & $86.29 \pm 1.44^{*}$ \\
\hline \multirow{8}{*}{$\begin{array}{l}\text { Ziziphus } \\
\text { mauritiana }\end{array}$} & Hex & Bark & NA & $106.32 \pm 2.80$ & $34.76 \pm 2.18^{\mathrm{a}}$ & $4.91 \pm 0.14^{*}$ & $34.90 \pm 3.06^{*}$ \\
\hline & Hex & Leaf & NA & $>$ & $46.17 \pm 4.73^{\mathrm{a}, \mathrm{b}}$ & $7.06 \pm 0.75^{*}$ & $53.50 \pm 2.79^{*}$ \\
\hline & EA & Bark & $131.96 \pm 2.27^{\mathrm{b}, \mathrm{c}}$ & $>$ & $\begin{array}{c}84.16 \pm \\
11.85^{\text {b,c,d,ef,g,h }}\end{array}$ & $48.98 \pm 2.38$ & $69.06 \pm 3.45^{*}$ \\
\hline & EA & Leaf & $52.60 \pm 0.47^{\mathrm{a}}$ & $>$ & $89.45 \pm 5.51^{\mathrm{d}, \mathrm{e}, \mathrm{f}, \mathrm{g}, \mathrm{h}, \mathrm{i}}$ & $22.85 \pm 1.93$ & $68.75 \pm 1.01 *$ \\
\hline & $\mathrm{MeoH}$ & Bark & $574.86 \pm 14.05^{\mathrm{j}}$ & $>$ & $224.10 \pm 12.63^{\circ}$ & $90.61 \pm 1.14$ & $85.80 \pm 1.61$ \\
\hline & $\mathrm{MeoH}$ & Leaf & $298.80 \pm 13.11^{\mathrm{f}, \mathrm{g}}$ & $139.27 \pm 1.09^{*}$ & $136.90 \pm 10.66^{\mathrm{j}, \mathrm{k}}$ & $59.94 \pm 0.91 *$ & $83.73 \pm 1.49$ \\
\hline & $\mathrm{H}_{2} \mathrm{O}$ & Bark & $188.63 \pm 15.23^{\mathrm{c}, \mathrm{d}}$ & $333.31 \pm 6.22 *$ & $91.54 \pm 7.84^{\mathrm{d}, \mathrm{e}, \mathrm{f}, \mathrm{g}, \mathrm{h}, \mathrm{i}}$ & $43.40 \pm 3.28$ & $78.02 \pm 2.23 *$ \\
\hline & $\mathrm{H}_{2} \mathrm{O}$ & Leaf & $475.64 \pm 22.20^{\mathrm{i}}$ & $102.71 \pm 6.55$ & $168.99 \pm 12.29^{\mathrm{k}, \mathrm{lm}, \mathrm{n}}$ & $85.32 \pm 1.80$ & $84.32 \pm 2.25^{*}$ \\
\hline \multirow{8}{*}{$\begin{array}{l}\text { Lawsonia } \\
\text { inermis }\end{array}$} & Hex & Bark & $261.76 \pm 20.37^{\mathrm{e}, \mathrm{f}}$ & $324.49 \pm 27.07$ & $86.18 \pm 13.54^{\mathrm{c}, \mathrm{d}, \mathrm{e}, \mathrm{f}, \mathrm{g}, \mathrm{h}}$ & $68.96 \pm 1.29$ & $77.38 \pm 4.56$ \\
\hline & Hex & Leaf & NA & $>$ & $68.71 \pm 15.40^{\mathrm{a}, \mathrm{b}, \mathrm{c}, \mathrm{d}}$ & $11.52 \pm 1.64 *$ & $67.81 \pm 4.27 *$ \\
\hline & EA & Bark & $804.59 \pm 28.61^{1}$ & $73.04 \pm 0.80 *$ & $176.71 \pm 14.04^{1, \mathrm{~m}, \mathrm{n}}$ & $93.30 \pm 0.19$ & $87.42 \pm 2.45$ \\
\hline & EA & Leaf & $70.91 \pm 14.50^{\mathrm{a}, \mathrm{b}}$ & $698.04 \pm 13.02$ & $127.38 \pm 5.65^{\mathrm{i}, \mathrm{j}}$ & $27.53 \pm 0.92 *$ & $59.77 \pm 2.31 *$ \\
\hline & $\mathrm{MeoH}$ & Bark & $965.09 \pm 18.15^{\mathrm{m}}$ & $34.84 \pm 0.93^{*}$ & $189.74 \pm 14.88^{\mathrm{m}, \mathrm{n}, \mathrm{o}}$ & $93.47 \pm 0.27$ & $88.80 \pm 0.70$ \\
\hline & $\mathrm{MeoH}$ & Leaf & $168.89 \pm 7.18^{\mathrm{c}, \mathrm{d}}$ & $194.21 \pm 2.99 *$ & $85.88 \pm 28.42^{\mathrm{c}, \mathrm{d}, \mathrm{e}, \mathrm{f}, \mathrm{g}, \mathrm{h}}$ & $55.59 \pm 3.68 *$ & $86.07 \pm 7.76$ \\
\hline & $\mathrm{H}_{2} \mathrm{O}$ & Bark & $386.43 \pm 14.88^{\mathrm{h}}$ & $103.63 \pm 3.82 *$ & $92.47 \pm 10.66^{\mathrm{d}, \mathrm{e}, \mathrm{f}, \mathrm{g}, \mathrm{h}, \mathrm{i}}$ & $77.79 \pm 0.26^{*}$ & $87.39 \pm 2.31$ \\
\hline & $\mathrm{H}_{2} \mathrm{O}$ & Leaf & $348.45 \pm 25.15^{\mathrm{g}, \mathrm{h}}$ & $154.15 \pm 40.88$ & $79.00 \pm 27.34^{\mathrm{b}, \mathrm{c}, \mathrm{d}, \mathrm{e}, \mathrm{f}, \mathrm{g}}$ & $77.86 \pm 2.91$ & $86.10 \pm 5.74$ \\
\hline
\end{tabular}




\begin{tabular}{|c|c|c|c|c|c|c|c|}
\hline \multirow{8}{*}{$\begin{array}{l}\text { Ocimum } \\
\text { basilicum }\end{array}$} & Hex & Bark & NA & $>$ & $55.92 \pm 2.76^{\mathrm{a}, \mathrm{b}, \mathrm{c}, \mathrm{d}}$ & $10.27 \pm 0.41 *$ & $62.27 \pm 1.14^{*}$ \\
\hline & Hex & Leaf & NA & $>$ & $155.53 \pm 4.75^{\mathrm{j}, \mathrm{k}, 1, \mathrm{~m}}$ & $8.97 \pm 1.32$ & $51.68 \pm 4.00 *$ \\
\hline & EA & Bark & $12.89 \pm 5.78^{\mathrm{a}}$ & $>$ & $78.62 \pm 4.77^{\mathrm{b}, \mathrm{c}, \mathrm{d}, \mathrm{e}, \mathrm{f}}$ & $18.35 \pm 3.13$ & $73.33 \pm 1.60^{*}$ \\
\hline & EA & Leaf & NA & $>$ & $118.71 \pm 13.28^{\mathrm{e}, \mathrm{f}, \mathrm{g}, \mathrm{h}, \mathrm{i}, \mathrm{j}}$ & $16.10 \pm 1.38$ & $71.91 \pm 2.71^{*}$ \\
\hline & $\mathrm{MeoH}$ & Bark & $223.48 \pm 18.43^{\mathrm{d}, \mathrm{e}}$ & $>$ & $91.60 \pm 17.52^{\mathrm{d}, \mathrm{e}, \mathrm{f}, \mathrm{g}, \mathrm{h}, \mathrm{i}}$ & $44.88 \pm 1.56^{*}$ & $86.05 \pm 2.90$ \\
\hline & Meoh & Leaf & $57.06 \pm 1.48^{\mathrm{a}}$ & $>$ & $71.85 \pm 7.41^{\mathrm{a}, \mathrm{b}, \mathrm{c}, \mathrm{d}}$ & $16.11 \pm 0.32 *$ & $69.24 \pm 1.34^{*}$ \\
\hline & $\mathrm{H}_{2} \mathrm{O}$ & Bark & $220.80 \pm 17.44^{\mathrm{d}, \mathrm{e}}$ & $>$ & $70.51 \pm 15.26^{\mathrm{a}, \mathrm{b}, \mathrm{c}, \mathrm{d}}$ & $38.05 \pm 1.55^{*}$ & $85.75 \pm 5.76$ \\
\hline & $\mathrm{H}_{2} \mathrm{O}$ & Leaf & $170.43 \pm 3.7^{\mathrm{c}, \mathrm{d}}$ & $>$ & $74.08 \pm 9.01^{\mathrm{b}, \mathrm{c}, \mathrm{d}}$ & $37.27 \pm 4.71 *$ & $80.98 \pm 1.56^{*}$ \\
\hline \multirow{8}{*}{$\begin{array}{c}\text { Punica } \\
\text { granatum }\end{array}$} & Hex & Seed & NA & $>$ & $53.29 \pm 8.15^{\mathrm{a}, \mathrm{b}, \mathrm{c}, \mathrm{d}}$ & $4.24 \pm 0.62$ & $53.11 \pm 4.96^{*}$ \\
\hline & Hex & Leaf & NA & $>$ & $117.79 \pm 5.37^{\mathrm{f}, \mathrm{g}, \mathrm{h}, \mathrm{i}, \mathrm{j}}$ & $9.26 \pm 0.98 *$ & $62.33 \pm 4.16^{*}$ \\
\hline & EA & Seed & $45.88 \pm 9.88^{\mathrm{a}}$ & $567.37 \pm 8.44^{*}$ & $74.72 \pm 7.40^{\mathrm{b}, \mathrm{c}, \mathrm{d}}$ & $27.92 \pm 1.70$ & $76.51 \pm 3.41^{*}$ \\
\hline & EA & Leaf & $61.40 \pm 4.81^{\mathrm{a}, \mathrm{b}}$ & $633.59 \pm 31.18 *$ & $77.47 \pm 11.65^{\mathrm{b}, \mathrm{c}, \mathrm{d}, \mathrm{e}}$ & $32.50 \pm 2.99^{*}$ & $76.54 \pm 3.04^{*}$ \\
\hline & $\mathrm{MeoH}$ & Seed & $979.28 \pm 48.38^{\mathrm{m}}$ & $36.58 \pm 1.02 *$ & $132.58 \pm 11.19^{\mathrm{j}, \mathrm{k}}$ & $94.01 \pm 0.28$ & $90.19 \pm 0.09$ \\
\hline & $\mathrm{MeoH}$ & Leaf & $1006.86 \pm 40.45^{\mathrm{n}}$ & $37.53 \pm 1.71^{*}$ & $139.02 \pm 4.51^{\mathrm{j}, \mathrm{k}, 1}$ & $93.93 \pm 0.27$ & $89.41 \pm 1.51$ \\
\hline & $\mathrm{H}_{2} \mathrm{O}$ & Seed & $630.25 \pm 54.62^{j}$ & $55.94 \pm 3.62 *$ & $88.72 \pm 4.49^{\mathrm{d}, \mathrm{e}, \mathrm{f}, \mathrm{g}, \mathrm{h}, \mathrm{i}}$ & $92.95 \pm 0.09 *$ & $87.32 \pm 0.78$ \\
\hline & $\mathrm{H}_{2} \mathrm{O}$ & Leaf & $968.18 \pm 75.28^{\mathrm{m}}$ & $41.46 \pm 0.70 *$ & $118.15 \pm 2.99^{\mathrm{g}, \mathrm{h}, \mathrm{i}, \mathrm{j}}$ & $94.01 \pm 0.21$ & $86.82 \pm 1.90$ \\
\hline \multirow[b]{2}{*}{$\begin{array}{c}\text { Standard } \\
\text { compounds }\end{array}$} & & $\begin{array}{c}\text { Gallic } \\
\text { acid }\end{array}$ & $\mathrm{ND}$ & $5.56 \pm 0.70$ & ND & & \\
\hline & & $\begin{array}{c}\text { Gallic } \\
\text { acid } \\
(100 \mu \mathrm{g} / \\
\mathrm{mL})\end{array}$ & & & & $94.05 \pm 0.25$ & $88.58 \pm 1.42$ \\
\hline
\end{tabular}

$\mathrm{Hex}=$ Hexane, $\mathrm{EA}=$ Ethyl acetate, $\mathrm{MeOH}=$ Methanol, $\mathrm{H}_{2} \mathrm{O}=$ Water

$\mathrm{NA}=$ No activity, $\mathrm{ND}=$ not detected, $>=\mathrm{E}_{\mathrm{C}} 50$ more than $1 \mathrm{mg} / \mathrm{mL}$

The $(a-m)$ symbol denotes a significant difference between sample $(\mathrm{p}<0.05)$

The $(*)$ symbol denote a significant difference between sample and standard drug $(\mathrm{p}<0.05)$

In DPPH assay, the methanol extracts for the leaves and bark of $D$. aromatica together with gallic acid gave scavenging activities $\mathrm{EC}_{50}$ at 19.32, 24.86, and $5.56 \mu \mathrm{g} /$ $\mathrm{mL}$, respectively. Both extracts exhibited good radical scavenging activity, which was close to the standard compound as seen in Table 1. Another anti-oxidant assay used to measure the radical scavenging activities is the ABTS assay. The green-blue stable radical cationic chromophore, 2,2-azinobis-(3-ethylbenzothiazoline6-sulfonate) $\left(\mathrm{ABTS}^{\circ+}\right)$ is produced by oxidation. In the presence of anti-oxidant compounds, this cationic radical can receive an electron or hydrogen and becomes a stable diamagnetic molecule (Roberta et al. 1999). Table 1 shows the free radical scavenging ABTS assay of all extracts from the five plants. Almost all polar extracts, such as the methanol extracts of the leaves and bark of $D$. aromatica, gave a similar percentage of ABTS scavenging activities compared to standard compound gallic acid, except for $O$. basilicum. This could be due to the low phenolic and flavonoid contents observed in $O$. basilicum extracts. The TAOC assay is a non-enzymatic assay that is capable in measuring the anti-oxidant capacity directly. It quantifies the presence of antioxidants by formation of green phosphate molybdenum V from reducing anti-oxidant activity (Prieto et al. 1999).

The TAOC values for all extracts are displayed in Table 1 . The highest TAOC value was exhibited by the methanol extract of the bark of $Z$. mauritiana with a value of $224.10 \mathrm{AAE}$, followed by the methanol extracts of the bark and leaves of $D$. aromatica with values of 
225.22 and 203.05 AAE, respectively. Meanwhile, for the $\mathrm{BCB}$ assay, the principle is to measure the ability of an anti-oxidant to inhibit lipid peroxidation. The model system of this assay is to make the beta-carotene and linoleic acid undergo a rapid discoloration in the absence of an anti-oxidant (Othman et al. 2014). The percentage inhibitions by each extract together with the standard compound are shown in Table 1. In the BCB assay, most methanol extracts for each plant showed good beta-carotene bleaching and comparable to BHT (an antioxidant compound). Each anti-oxidant assay mentioned measures the anti-oxidant activity of the extracts based on different reaction mechanisms, leading to different results. It is important to determine which extract has good activities in all the anti-oxidant assays. From this research, it is shown that the methanol extract of the leaves from $D$. aromatica showed good anti-oxidant activity on all the anti-oxidant tests, which can be due to the high phenolic content in the extracts.

The alpha-glucosidase inhibitory and the antioxidant results obtained may be attributed to $D$. aromatica genus which had been reported to be a source of resveratrol oligomers such as trans-3,4',5trihydroxystilbene and bergenin. These oligomers were reported to have several bioactivities such as antidiabetic and anti-oxidant activities (Wibowo et al. 2012, 2011). Other than that, P. granatum had been reported to exhibit anti-oxidant and anti-diabetic activities (Radhika et al. 2011; Zhang et al. 2010). L. inermis leaf extract was reported to have exhibited anti-diabetic activity in diabetic mice (Syamsudin \& Winarno 2008) and also have anti- oxidant biological activity (Agarwal et al. 2014). Studies on Z. mauritiana had shown anti-diabetic (Ganesh \& Amit 2013) and anti-oxidant properties (Salleh et al. 2019). Lastly, O. basilicum had been reported to have anti-oxidant activity (Ahmad et al. 2015) and the aqueous extract showed potential anti-diabetic activities when tested for hypoglycemic activity (El-Beshbishy \& Bahashwan 2012). According to Radhika et al. (2011), plants with anti-oxidant properties have the potential to treat diabetes due to their therapeutic benefits.

Since methanol extracts of the leaves and bark of D. aromatica showed the most potentials for anti-oxidant and anti-diabetic activities, the chemical contents of both extracts were further profiled using GCMS (for volatile compounds) and LCMS (for non-volatile compounds. Figure 4(a) and 4(b) shows LCMS chromatograms of methanol extracts of $D$. aromatica leaves and bark, respectively. It can be seen that both spectra showed a similar pattern. Based on the library (Metlin and Chemspider database), 12 phytochemical compounds were identified in both extracts (Tables 2 and 3). The compounds are spirilloxanthin, spinoside A, 8E,11Zhexadecadienal, nostocyclopeptide A3, scytophycin C, $\alpha$-viniferin, $\varepsilon$-viniferin, kurilensoside I, methyl gallate, clerodin, $\mathrm{N}$-linoleoyl taurine, and guazatine. Previous report indicated that $D$. aromatica was rich with oligostilbenoid that gave rise to biological activities. Compounds such as $\varepsilon$-viniferin in extracts of $D$. aromativa yielded cytotoxic activities against two cancer cell lines, MCF7 and A549 (Wibowo et al. 2014). Meanwhile, $\alpha$-viniferin was found to give good anti-proliferative activity against HL-60 cell line (Wibowo et al. 2011).
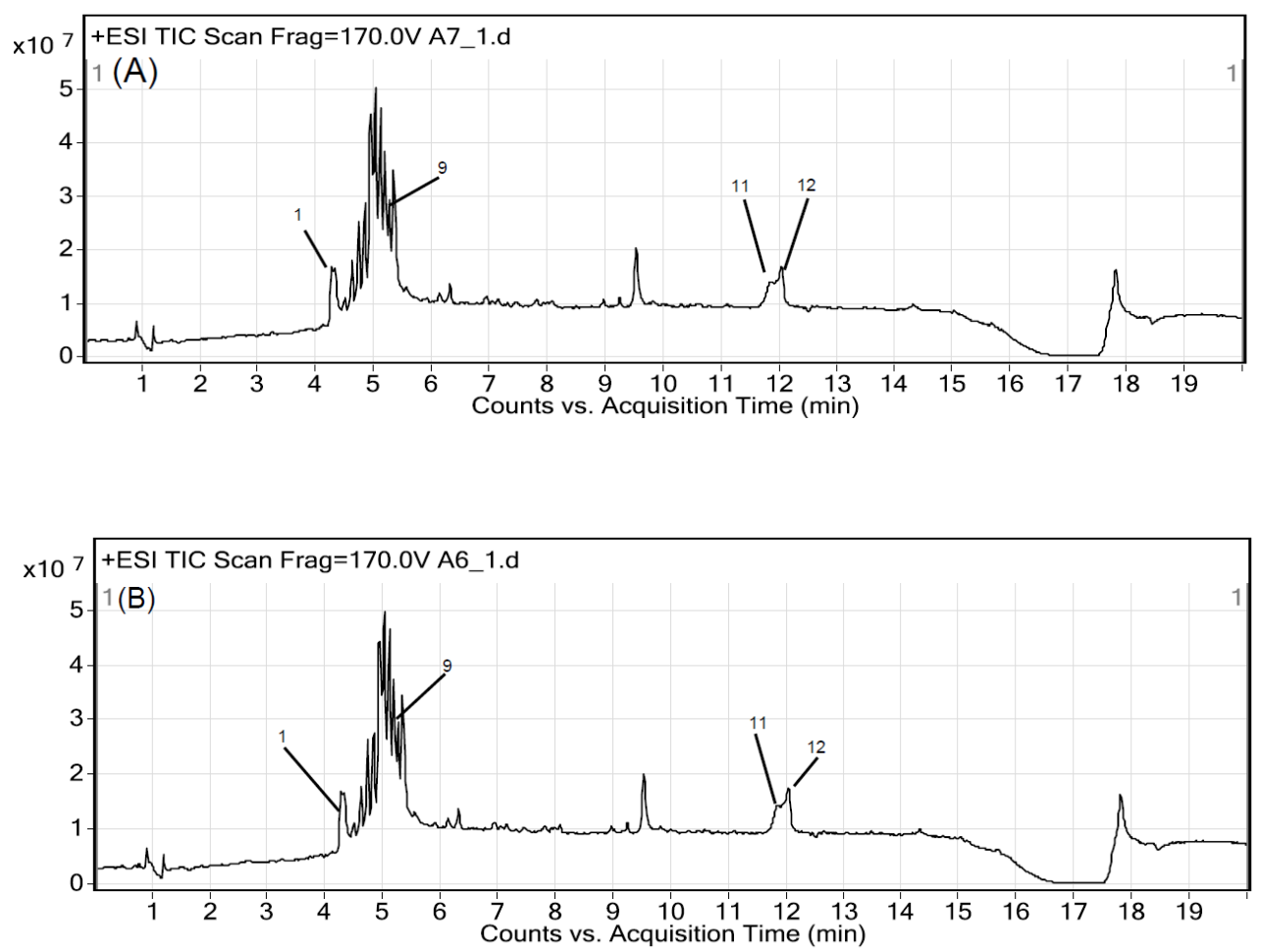

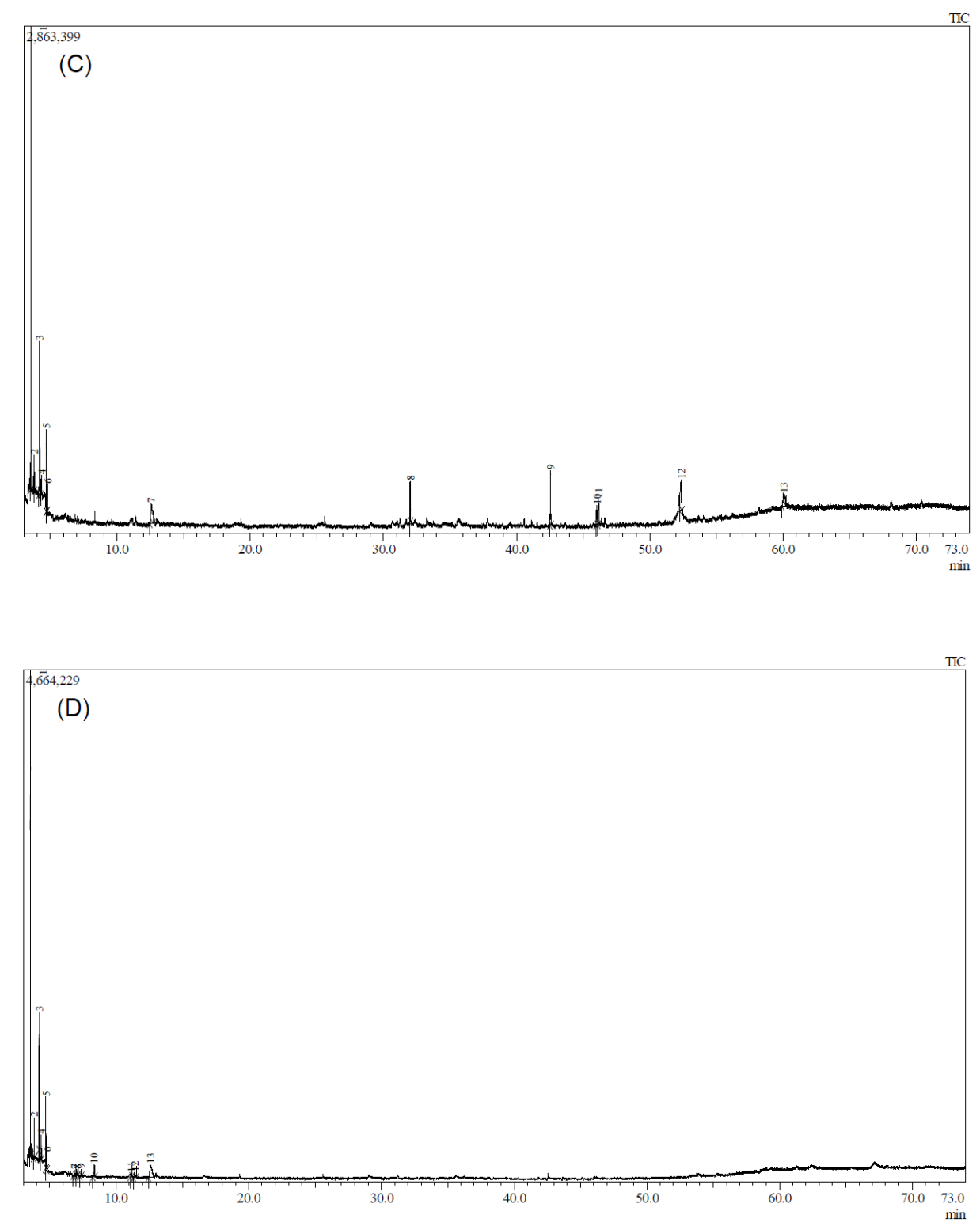

FIGURE 4. Typical total ion chromatograms for phytochemical analysis, (A) LCMS analysis of methanol extracts of $D$. aromatica leaves, (B) LCMS analysis of methanol extracts of $D$. aromatica barks, (C) GCMS analysis of methanol extracts of D. aromatica leaves, and (D) GCMS analysis of methanol extracts of $D$. aromatica barks

Meanwhile, phytochemical analysis of the volatile components was performed using GCMS for both of the active extracts (Figure 4(c) and 4(d)). The profiling of two $D$. aromatica extracts with GCMS showed that there are 13 metabolites appeared in each extract. Of the
13 metabolites in D. aromatica methanol leaves extract, 11 compounds were assigned with a compound name while two compounds were labeled as 'unknown' since the SI of these compounds did not achieve $80 \%$ when the mass spectrum was compared with the NIST library 
(Table 4). Meanwhile, 8 compounds were assigned out of 13 metabolites from $D$. aromatica methanol bark extract based on the NIST library (Table 5). Five similar compounds were found in both extracts which were performic acid, acetic acid, decane, glycerine, and propanoic acid. It is thus suggested that these compounds which were present in both extracts contributed to the anti-oxidant and anti-diabetic activities of $D$. aromatica. Performic acid appeared abundantly in both extracts and is known as a disinfectant agent used in the food industry as it has antibacterial properties (Helvi \& Harri 2010).

TABLE 2. Information on the metabolites of Dryobalanops aromatica leaves methanol extract analyzed using LCMS

\begin{tabular}{cccccc}
\hline No & $\mathrm{RT}(\mathrm{min})$ & Ion & Molecular formula & Measured mass (m/Z) & Tentative identification \\
\hline 1 & 4.108 & {$[\mathrm{M}+\mathrm{H}]^{+}$} & $\mathrm{C}_{42} \mathrm{H}_{60} \mathrm{O}_{2}$ & 597.4696 & Spirilloxanthin \\
2 & 4.612 & {$[\mathrm{M}+\mathrm{H}]^{+}$} & $\mathrm{C}_{39} \mathrm{H}_{56} \mathrm{O}_{12}$ & 717.3855 & Spinoside A \\
3 & 4.792 & {$[\mathrm{M}+\mathrm{H}]^{+}$} & $\mathrm{C}_{16} \mathrm{H}_{28} \mathrm{O}$ & 237.2204 & $8 \mathrm{E}, 11$ Z-hexadecadienal \\
4 & 4.829 & {$[\mathrm{M}+\mathrm{H}]^{+}$} & $\mathrm{C}_{41} \mathrm{H}_{56} \mathrm{~N}_{8} \mathrm{O}_{9}$ & 805.4277 & Nostocyclopeptide A3 \\
5 & 4.926 & {$[\mathrm{M}+\mathrm{H}]^{+}$} & $\mathrm{C}_{45} \mathrm{H}_{75} \mathrm{NO}_{11}$ & 828.5213 & Scytophycin C \\
6 & 5.015 & {$[\mathrm{M}+\mathrm{H}]^{+}$} & $\mathrm{C}_{43} \mathrm{H}_{72} \mathrm{O}_{19}$ & 428.3240 & Kurilensoside I \\
7 & 5.016 & {$[\mathrm{M}+\mathrm{H}]^{+}$} & $\mathrm{C}_{28} \mathrm{H}_{22} \mathrm{O}_{6}$ & 455.8115 & $\varepsilon$-viniferin \\
8 & 5.057 & {$[\mathrm{M}+\mathrm{H}]^{+}$} & $\mathrm{C}_{8} \mathrm{H}_{8} \mathrm{O}_{5}$ & 185.1606 & Methyl gallate \\
9 & 5.198 & {$[\mathrm{M}+\mathrm{H}]^{+}$} & $\mathrm{C}_{24} \mathrm{H}_{34} \mathrm{O}_{7}$ & 435.2377 & Clerodin \\
10 & 7.791 & {$[\mathrm{M}+\mathrm{H}]^{+}$} & $\mathrm{C}_{20} \mathrm{H}_{37} \mathrm{NO}_{4} \mathrm{~S}$ & 388.2534 & N-linoleoyl taurine \\
11 & 11.877 & {$[\mathrm{M}+\mathrm{H}]^{+}$} & $\mathrm{C}_{42} \mathrm{H}_{30} \mathrm{O}_{9}$ & 669.4432 & $\alpha$-viniferin \\
12 & 12.049 & {$[\mathrm{M}+\mathrm{H}]^{+}$} & $\mathrm{C}_{18} \mathrm{H}_{41} \mathrm{~N}_{7}$ & 356.3486 & Guazatine \\
\hline
\end{tabular}

TABLE 3. Information on the metabolites of Dryobalanops aromatica bark methanol extract analyzed using LCMS

\begin{tabular}{cccccc}
\hline No & $\mathrm{RT}(\mathrm{min})$ & Ion & Molecular formula & Measured mass $(\mathrm{m} / \mathrm{Z})$ & Tentative identification \\
\hline 1 & 4.107 & {$[\mathrm{M}+\mathrm{H}]^{+}$} & $\mathrm{C}_{24} \mathrm{H}_{60} \mathrm{O}_{2}$ & 597.4695 & Spirilloxanthin \\
2 & 4.612 & {$[\mathrm{M}+\mathrm{H}]^{+}$} & $\mathrm{C}_{39} \mathrm{H}_{56} \mathrm{O}_{12}$ & 717.3855 & Spinoside A \\
3 & 4.610 & {$[\mathrm{M}+\mathrm{H}]^{+}$} & $\mathrm{C}_{16} \mathrm{H}_{28} \mathrm{O}$ & 237.2204 & $8 \mathrm{E}, 11$ Z-hexadecadienal \\
4 & 4.824 & {$[\mathrm{M}+\mathrm{H}]^{+}$} & $\mathrm{C}_{41} \mathrm{H}_{56} \mathrm{~N}_{8} \mathrm{O}_{9}$ & 805.4277 & Nostocyclopeptide A3 \\
5 & 4.922 & {$[\mathrm{M}+\mathrm{H}]^{+}$} & $\mathrm{C}_{45} \mathrm{H}_{75} \mathrm{NO}_{11}$ & 828.5213 & Scytophycin C \\
6 & 5.011 & {$[\mathrm{M}+\mathrm{H}]^{+}$} & $\mathrm{C}_{43} \mathrm{H}_{72} \mathrm{O}_{19}$ & 428.3240 & Kurilensoside I \\
7 & 5.012 & {$[\mathrm{M}+\mathrm{H}]^{+}$} & $\mathrm{C}_{28} \mathrm{H}_{22} \mathrm{O}_{6}$ & 455.8115 & -viniferin \\
8 & 5.052 & {$[\mathrm{M}+\mathrm{H}]^{+}$} & $\mathrm{C}_{8} \mathrm{H}_{8} \mathrm{O}_{5}$ & 185.1607 & Methyl Gallate \\
9 & 5.195 & {$[\mathrm{M}+\mathrm{H}]^{+}$} & $\mathrm{C}_{24} \mathrm{H}_{34} \mathrm{O}_{7}$ & 435.2377 & Clerodin \\
10 & 7.789 & {$[\mathrm{M}+\mathrm{H}]^{+}$} & $\mathrm{C}_{20} \mathrm{H}_{37} \mathrm{NO}_{4} \mathrm{~S}$ & 388.2534 & N-linoleoyl Taurine \\
11 & 11.875 & {$[\mathrm{M}+\mathrm{H}]^{+}$} & $\mathrm{C}_{42} \mathrm{H}_{30} \mathrm{O}_{9}$ & 669.4438 & $\alpha$-viniferin \\
12 & 12.048 & {$[\mathrm{M}+\mathrm{H}]^{+}$} & $\mathrm{C}_{18} \mathrm{H}_{41} \mathrm{~N}_{7}$ & 356.3486 & Guazatine \\
\hline
\end{tabular}


TABLE 4. Information on metabolites of Dryobalanops aromatica leaves methanol extract analyzed using GCMS

\begin{tabular}{ccccc}
\hline Peak & $\begin{array}{c}\text { R. Time } \\
(\mathrm{min})\end{array}$ & Area $(\%)$ & SI & Compound name \\
\hline 1 & 3.52 & 24.86 & 86 & Performic acid \\
2 & 3.78 & 2.21 & 92 & Acetic acid \\
3 & 4.17 & 10.73 & 91 & Glycerin \\
4 & 4.33 & 1.24 & 90 & Propanoic acid \\
5 & 4.69 & 6.20 & 94 & Glycerin \\
6 & 4.77 & 2.35 & 77 & Unknown \\
7 & 12.56 & 10.97 & 93 & Decane \\
8 & 32.0 & 7.07 & 94 & Dodecanoic acid \\
9 & 42.55 & 8.54 & 95 & 9,12 -octadecadienoic acid \\
10 & 46.03 & 2.57 & 90 & Cyclopropanebutanoic acid \\
11 & 46.15 & 4.86 & 84 & Unknown \\
12 & 52.35 & 11.28 & 81 & ethenye-10,14-dimethylene- pentadic-4-enyl) cyclohexane \\
13 & 60.05 & 7.11 & 63 & 1,6-trimethyl-3-methylene-2-(3,6,9,13-tetramethyl-6- \\
\hline
\end{tabular}

TABLE 5. Information on metabolites of Dryobalanops aromatica bark methanol extract analyzed using GCMS

\begin{tabular}{ccccc}
\hline Peak & $\begin{array}{c}\text { R. Time } \\
(\mathrm{min})\end{array}$ & Area $(\%)$ & SI & Compound name \\
\hline 1 & 3.54 & 41.43 & 86 & Performic acid \\
2 & 3.80 & 4.23 & 94 & Acetic acid \\
3 & 4.19 & 14.12 & 92 & Glycerin \\
4 & 4.35 & 3.26 & 96 & Propanoic acid \\
5 & 4.72 & 11.07 & 95 & Glycerin \\
6 & 4.79 & 2.38 & 76 & Unknown \\
7 & 6.85 & 1.47 & 81 & p-Dioxane-2,3-diol \\
8 & 7.05 & 1.11 & 66 & Unknown \\
9 & 7.35 & 1.37 & 79 & Unknown \\
10 & 8.34 & 2.63 & 72 & Unknown \\
11 & 11.137 & 1.01 & 79 & Unknown \\
12 & 11.40 & 1.35 & 84 & Octane \\
13 & 12.56 & 13.58 & 95 & Decane \\
\hline
\end{tabular}




\section{CONClusion}

It can be concluded from the current study, that out of all the plant extracts investigated, the methanol extracts of $D$. aromatica showed potential in inhibiting alphaglucosidase, as well as containing high anti-oxidant properties. The results obtained corroborate with the claim that plants with anti-oxidant properties could have correlations with anti-diabetic properties. Thus, the current study could suggest that the anti-oxidant activities of $D$. aromatica extracts might have some association with the anti-diabetic effects of these extracts. This is the first report that highlights the antidiabetic potential of $D$. aromatica. Therefore, further investigation is warranted on $D$. aromatica, where bioassay-guided isolation of the potent extracts and phytochemical characterization of isolated bioactive constituents can be performed. Further work on this plant will open up more options in the management and treatment of diabetes.

\section{ACKNOWLEDGEMENTS}

This study was funded by the Ministry of Higher Education through the Trans Disciplinary Research Grant Scheme (TR001C-2014A), and USIM C grant (PPP/ UCG-0116/FPQS/30/14316).

\section{REFERENCES}

Agarwal, P., Alok, S. \& Verma, A. 2014. An update on ayurvedic herb Henna (Lawsonia inermis L.): A review. International Journal of Pharmaceutical Sciences and Research 5(2): 330-339.

Ahmad, C.M., Naz, S.B., Sharif, A., Akram, M. \& Saeed, M.A. 2015. Biological and pharmacological properties of the sweet basil (Ocimum basilicum). British Journal of Pharmaceutical Research 7(75): 330-339.

Ali, M. 2014. Therapeutic flora in Holy Quran. African Journal of History and Culture 6(9): 141-148.

Alia, B., Bashir, A. \& Tanira, M. 1995. Anti-inflammatory, antipyretic, and analgesic effects of Lawsonia inermis L.(henna) in rats. Pharmacology 51(6): 356-363.

American Diabetes Association. 2010. Diagnosis and classification of diabetes mellitus. Diabetes Care 29: 43-48.

Ashton, P.S. 1983. Spermatophyta. In Flora Malesiana, edited by van Steenis, C.G.G.J. The Hague: Martinus Nijihoff Publishers. p. 9.

Badoni Semwal, R., Semwal, D.K., Combrinck, S., Cartwright-Jones, C. \& Viljoen, A. 2014. Lawsonia inermis L. (henna): Ethnobotanical, phytochemical and pharmacological aspects. Journal of Ethnopharmacology 5(1): 80-103.
Ceriello, A. 2000. Oxidative stress and glycemic regulation. Metabolism 49: 27-29.

Chen, X., Bai, X., Liu, Y., Tian, L., Zhou, J., Zhou, Q., Zhou, J. \& Chen, J. 2009. Anti-diabetic effects of water extract and crude polysaccharides from tuberous root of Liriope spicata var. prolifera in mice. Journal Ethnopharmacology 122(2): 205-209.

Cheng, A.Y.Y. \& Josse, R.G. 2004. Intestinal absorption inhibitors for Type 2 diabetes mellitus: Prevention and treatment. Drug Discovery Today: Therapeutic Strategies 1: 201-206.

Cunningham, J.J. 1998. Micronutrients as nutriceutical interventions in diabetes mellitus. The Journal of the American College of Nutrition 17: 7-12.

Dehghan, H., Sarrafi, Y. \& Salehi, P. 2016. Anti-oxidant and antidiabetic activities of 11 herbal plants from Hyrcania region. Iran Journal Food Drug Analysis 24: 179-188.

Deutschländer, M.S., Venter, M., Roux, S., Louw, J. \& Lall, N. 2009. Hypoglycaemic activity of four plant extracts traditionally used in South Africa for diabetes. Journal Ethnopharmacology 124(3): 619-624.

Donkin, R.A. 1999. Dragon's Brain Perfume: An Historical Geography of Camphor. Leiden, Netherlands: Brill Academic Publisher.

Dudonné, S., Vitrac, X., Coutiere, P., Woillez, M. \& Merillon, J.M. 2009. Comparative study of anti-oxidant properties and total phenolic content of 30 plant extracts of industrial interest using DPPH, ABTS, FRAP, SOD and ORAC assays. Journal of Agriculture \& Food Chemistry 57: 17681774 .

El-Beshbishy, H. \& Bahashwan, S. 2012. Hypoglycemic effect of basil (Ocimum basilicum) aqueous extract is mediated through inhibition of $\alpha$-glucosidase and $\alpha$-amylase activities: An in vitro study. Toxicology \& Industrial Health 28(1): 42-50.

Ganesh, N.S. \& Amit, G. 2013. Ziziphus mauritiana Lam An overview. Indo American Journal of Pharmaceutical Research 3(6): 4560-4566.

Handa, S.S., Khanuja, S.P.S., Longo, G. \& Rakesh, D.D. 2008. Extraction Technologies for Medicinal and Aromatic Plants. Italy, Trieste: ICS-UNIDO.

Heftmann, E., Ko, S.T. \& Bennett, R.D. 1966. Identification of estrogen in pomegranate seeds. Phytochemistry 5(6): $1337-1339$

Hollander, P. 1992. Safety profile of acarbose, an alphaglucosidsase inhibitor. Drugs 44(2): 21-23.

Helvi, H.T. \& Harri, M. 2010. Performic acid as a potential disinfectant at low temperature. Journal of Food Process Engineering 33: 1159-1172.

Jain, A., Bhatt, S.D.R. \& Dhyani, S. 2012. Phytochemical screening of secondary metabolites of Ziziphus mauritiana Lam. International Journal Current Pharmaceutical Research 4(3): 156-159. 
Jarald, E.E., Joshi, S.B. \& Jain, D.C. 2009. Anti-diabetic activity of extracts and fraction of Zizyphus mauritiana. Pharmacy Biology Journal 47(4): 328-334.

Kahkonen, M.P., Hopia, A.I., Vuorela, H.J., Rauha, J.P., Pihlaja, K. \& Kujala, T.S. 1999. Anti-oxidant activity of plant extracts containing phenolic compounds. Journal of Agricultural and Food Chemistry 47: 3954-3962.

Kazeem, M.I., Adamson, J.O. \& Ogunwande, I.A. 2013. Modes of inhibition of $\alpha$-amylase and $\alpha$-glucosidase by aqueous extract of Morinda lucida Benth leaf. BioMed Research International 2013: 1-6.

Kim, G.N., Shin, J.G. \& Jang, H.D. 2009. Anti-oxidant and antidiabetic activity of Dangyuja (Citrus grandis Osbeck) extract treated with Aspergillus saitoi. Food Chemistry 117(1): 35-41.

Kwon, Y.I., Apostolidis, E. \& Shetty, K. 2007. Evaluation of pepper (Capsicum annuum) for management of diabetes and hypertension. Journal of Food Biochemistry 31(3): 370-385.

Larson, R.A. 1988. The anti-oxidants of higher plants. Photochemical 27: 969-978.

Le, T.X., Ho, A.S.H., Mah, S.H., Wong, T.W., Ong, H.C., Loh, P.H.M. \& Lim, Y.M. 2016. Determination of borneol and other chemical compounds of essential oil of Dryobalanops aromatica exudate from Malaysia. Tropical Journal of Pharmaceutical Research 15(6): 1293-1297.

Marwat, S.K., Rehman, F.U., Khan, M.S., Ghulam, S., Anwar, N., Mustafa, G. \& Usman, K. 2011. Phytochemical constituents and pharmacological activities of sweet basil - Ocimum basilicum L. (Lamiaceae). Asian Journal of Chemistry 23: 3773-3782.

Moneam, N.M.A., El Sharaky, A.S. \& Badreldin, M.M. 1988. Oestrogen content of pomegranate seeds. Journal of Chromatography A 438(2): 438-442.

Muhammad, H.S. \& Muhammad, S. 2005. The use of Lawsonia inermis Linn. (henna) in the management of burn wound infections. African Journal of Biotech 4(9): 934-937.

Nair, S.S., Kavrekar, V. \& Mishra, A. 2013. In vitro studies on alpha-amylase and alpha-glucosidase inhibitory activities of selected plant extracts. European Journal of Experimental Biology 3(1): 128-132.

Nik, W.B.W., Zulkifli, F., Sulaiman, O., Samo, K.B. \& Rosliza, R. 2012. Study of henna (Lawsonia inermis) as natural corrosion inhibitor for aluminum alloy in seawater. IOP Conference Series: Materials Science and Engineering 36(1): 12-43.

Nordin, N., Mohan, S., Hashim, N.M., Zajmi, A., Yazid, N.S.M., Rahman, Omer, F.A.A., Omar, H., Alias, F.A. \& Ali, H.M. 2014. Anti-oxidant, anticancer and antimicrobial activities of methanolic extracts from Enicosanthellum pulchrum (King) Heusden. Sains Malaysiana 43(10): 15151521.

Norshazila Senawi, Syed Osman Idid Syed Zahir Idid, Koya Mustapha Suleiman, Aisyah Mohamed Rehan \& Kamarul
Rahim Kamarudin. 2010. Antioxidant level and activities of selected seed of Malaysian tropical fruits. Malaysian Journal of Nutrition 16(1): 149-159.

Ong, H.C. \& Norzalina, J. 1999. Malay herbal medicine in Gemencheh, Negeri Sembilan, Malaysia. Fitoterapia 70(1): 10-14.

Ong, H.C., Ruzalila, B.N. \& Milow, P. 2011. Traditional knowledge of medicinal plants among the Malay villagers in Kampung Tanjung Sabtu, Terengganu, Malaysia. Indian Journal of Traditional Knowledge 10(3): 460-465.

Othman, A., Mukhtar, N.J., Ismail, N.S. \& Chang, S.K. 2014. Phenolics, flavonoids content and antioxidant activities of 4 Malaysian herbal plants. International Food Research Journal 21(2): 759-766.

Othman, M.R., Othman, R., Ismail, A.A., Hazni, H., Ahmad, K., Razzak, M.A., Yusoff, Z.M. \& Awang, K. 2020. Highperformance liquid chromatography quadrupole time-offlight mass spectrometry (HPLC-QTOFMS) analysis on the ethanol: Water (80:20) extract of Lawsonia inermis leaves. Sains Malaysiana 49(7): 1597-1613.

Poyrazoğlu, E., Gökmen, V. \& Artı, N. 2002. Organic acids and phenolic compounds in pomegranates (Punica granatum 1.) grown in Turkey. Journal of Food Composition and Analysis 15(5): 567-575.

Prieto, P., Pineda, M. \& Aquilar, M. 1999. Spectrophotometric quantitation of antioxidant capacity through the formation of a phosphomolybdenum complex: Specific application to the determination of vitamin E. Analytical Biochemistry 269(2): 337-341.

Radhika, S., Smila, K.H. \& Muthezhilan, R. 2011. Antidiabetic and hypolipidemic activity of Punica granatum Linn. on alloxan induced rats. World Journal of Medical Sciences 6(4): 178-182.

Rahman, S. 2012. Anti-oxidant, analgesic, cytotoxic and antidiarrheal activities of ethanolic Ziziphus mauritiana bark extract. Oriental Pharmacy and Experimental Medicine 12(1): 67-73.

Rege, A.A. \& Chowdhary, A.S. 2014. Evaluation of alphaamylase and alpha-glucosidase inhibitory activities of Rhizophora mucronata. International Journal of Pharmaceutical Sciences and Research 25(22): 130-133.

Roberta, R., Nicoletta, P., Anna, P., Ananth, P., Min, Y. \& Catherine, R.E. 1999. Antioxidant activity applying an improved ABTS radical cation decolorization assay. Free Radical Biology and Medicine 26(9): 1231-1237.

Ruhomally, Z., Somanah, J., Bahorun, T. \& Neerghee-bhujun, V.S. 2015. Morinda citrifolia L. fruit extract modulates $\mathrm{H}_{2} \mathrm{O}_{2}$ - induced oxidative stress in human liposarcoma SW872 cell. Journal of Traditional and Complementary Medicine 6: 299-304.

Saeed, N., Khan, M.R. \& Shabbier, M. 2012. Anti-oxidant activity, total phenolic and total flavonoid content of whole plant extract Torilis leptophylla L. BMC Complementary and Alternative Medicine 12: 221. 
Salleh, H.M., Chong, S.L., Othman, R., Hazni, H., Ahmad, K., Mohd Yusof, M.Y.Z., Faauzi, N.W., Wahab, H.A., Liew, S.Y. \& Awang, K. 2019. Dengue protease inhibition activity of selected Malaysian medicinal herbs. Tropical Biomedicine 36(2): 357-366.

Shokeen, P., Anand, P., Murali, Y.K. \& Tandon, V. 2008. Antidiabetic activity of $50 \%$ ethanolic extract of Ricinus communis and its purified fractions. Food and Chemical Toxicology 46(11): 3458-3466.

Sivasothy, Y., Loo, K.Y., Leong, K.H., Litaudon, M. \& Awang, K. 2016. A potent alpha-glucosidase inhibitor from Myristica cinnamomea King. Phytochemistry 122: 265-269.

Sultana, N., Choudhary, M.I. \& Khan, A. 2009. Protein glycation inhibitory activities of Lawsonia inermis and its active principles. Journal of Enzyme Inhibition and Medicinal Chemistry 24(1): 257-261.

Sun, L., Zhang, J., Lu, X., Zhang, L. \& Zhang, Y. 2011. Evaluation to the anti-oxidant activity of total flavonoids extract from persimmon (Diospyros kaki L.) leaves. Food and Chemical Toxicology 49(10): 2689-2696.

Sun, Y.F., Liang, Z.S., Shan, C.J., Viernstein, H. \& Unger, F. 2011 Comprehensive evaluation of natural antioxidants and antioxidant potentials in Ziziphus jujuba Mill. var. spinosa (Bunge) Hu ex H. F. Chou fruits based on geographical origin by TOPSIS method. Food Chemistry 124(4): 16121619.

Syamsudin, I. \& Winarno, H. 2008. The effect of Inai (Lawsonia inermis Linn) leaves extract on blood sugar level: An experimental study. Research Journal of Pharmacology 2(2): $20-23$.

Szkudelski, T. \& Szkudelska, K. 2011. Anti-diabetic effects of resveratrol. Annals of the New York Academy of Sciences 1215(1): 34-39.

Tabussum, A., Riaz, N., Saleem, M., Ashraf, M., Ahmad, M., Alam, U., Jabeen, B., Malik, A. \& Jabbar, A. 2013. Alphaglucosidase inhibitory constituents from Chrozophora plicata. Phytochemistry Letter 6: 614-619.

Viuda-Martos, M., Fernández-López, J. \& Pérez-Álvarez, J.A. 2010. Pomegranate and its many functional components as related to human health: A review. Comprehensive Reviews in Food Science and Food Safety 9(6): 635-654.

Wibowo, A., Ahmat, N., Hamzah, A.S., Latif, F.A., Norrizah, J.S., Khong, H.Y. \& Takayama, H. 2014. Identification and biological activity of secondary metabolites from Dryobalanops beccarii. Phytochemistry Letters 9: 117122.

Wibowo, A., Ahmat, N., Hamzah, A.S., Ismail, N.H., Ahmad, R. \& Jaafar, F.M. 2012. Resveratrol oligomers from the stem bark of Dryobalanops aromatica. Biochemical Systematics and Ecology 40: 62-64.
Wibowo, A., Ahmat, N., Hamzah, A.S., Sufian, A.S., Ismail, N.H., Ahmad, R., Jaafara, F.M. \& Takayama, H. 2011 Malaysianol A, a new trimer resveratrol oligomer from the stem bark of Dryobalanops aromatica. Fitoterapia 82: 676-681.

Zamakshshari, N.Z., Ee, G.C.L., Ismail, I.S., Ibrahim, Z. \& Mah, S.H. 2019. Cytotoxic xanthones isolated from Calophyllum depressinervosum and Calophyllum buxifolium with antioxidant and cytotoxic activities. Food and Chemical Toxicology 133: 110800.

Zhang, L., Gao, Y., Zhang, Y., Liu, J. \& Yu, J. 2010. Changes in bioactive compounds and anti-oxidant activities in pomegranate leaves. Scientia Horticulturae 123(4): 543546.

Nooraqilah Che Rozenan, Leong Kok Hoong, Najihah Mohd Hashim, Abd Aziz Ismail \& Rozana Othman* Department of Pharmaceutical Chemistry

Faculty of Pharmacy

Universiti Malaya

50603 Kuala Lumpur, Federal Territory

Malaysia

Khadher Ahmad, Munirah Abd Razzak \& Zulkifli Mohd Yusoff Department of Al-Quran and Al-Hadith Academy of Islamic Studies

Universiti Malaya

50603 Kuala Lumpur, Federal Territory

Malaysia

Khalijah Awang

Department of Chemistry

Faculty of Science

Universiti Malaya

50603 Kuala Lumpur, Federal Territory

Malaysia

Nor Hisam Zamakshshari, Leong Kok Hoong, Najihah Mohd Hashim, Khalijah Awang \& Rozana Othman*

Centre for Natural Products Research and Drug Discovery (CENAR)

Universiti Malaya

50603 Kuala Lumpur, Federal Territory

Malaysia

*Corresponding author; email: rozanaothman@um.edu.my

Received: 17 August 2020

Accepted: 8 January 2021 